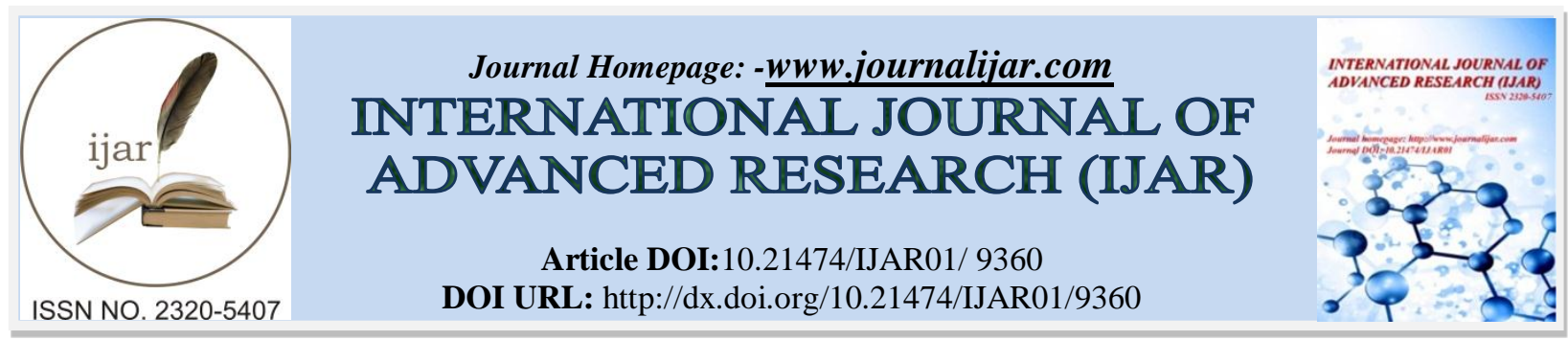

RESEARCH ARTICLE

\title{
THE IMPLEMENTATION OF PANTAWID PAMILYANG PILIPINO PROGRAM(4PS) AND ITS SOCIO- ECONOMIC IMPACT TO THE LIVING STANDARDS OF THE BENEFICIARIES IN TABUK CITY.
}

Raquel J. Dulliyao.

Kalinga State University.

\section{Manuscript Info}

Manuscript History

Received: 06 May 2019

Final Accepted: 08 June 2019

Published: July 2019

Key words:-

Pantawid Program in Tabuk City.

\section{Abstract}

The study assessed the Pantawid Pamilyang Pilipino Program(4Ps) and its socio economic impact to the living standard of the selected members from Tabuk with 140 respondents. The females were in greater number, married, aged 26-33 with a relatively low level of education.

The goals and objectives of the Program were moderately and the impact were further assessed as moderate though there was an increase in the enrolment and attendance rate. The incidence of child labor was reduced. Furthermore, the constraints have affected the implementation much seriously.

There is a need to device a built-in program that seek to ensure the economic sustainability for a longer time. The members, while receiving financial assistance should be indoctrinated, reoriented and trained to empower themselves through the provision of necessary skills and competencies that could help them earn sustainable income. Likewise, develop some mechanics to conduct proper monitoring and evaluation giving emphasis on the rightful attitude and character of a worthy recipient .. This maybe done by possibly helping them venture into productive activities while enjoying the benefit of the program.

As a corrective measure, enforce a policy giving full restriction on careless borrowing by using their cash cards as collateral. If possible, cashcards are released only to the rightful owners during pay-out. As such, they have nothing to use as collateral to abusive moneylenders, hence, helping the member instill discipline on cash handling and also discourage the habitual borrowing of money. Conduct regular monitoring to avoid misuse of financial assistance.

Copy Right, IJAR, 2019,. All rights reserved.

\section{Introduction:-}

As provided in Pantawid Pamilya Guide Booklet, Longan(2016) disclosed that the Pantawid Pamilyang Pilipino Program(4P's) is a program implemented by the National government of the Philippines nationwide among identified and selected beneficiaries. Under this program, conditional cash grants are given to, based on proper evaluation and qualification, the poorest of the poor purposely for health and nutrition improvement as well as to extend assistance for the education of children with ages ranging zero(0) to eighteen(18). The economic program is actually deduced from the conditional cash transfer(cct) scheme being practiced in the countries particularly Latin 
America and Africa of which, according to relevant reports have lifted millions of people around world from material and financial difficulties described better as poverty.

The program was actually named as Pantawid Pamilyang Pilipino Program(4P's) Santiago and Samantha A. Vizconde on July 16, 2008 with the issuance of Administrative Order \# 16 series of 2008 . Under the flagship of then President Benigno C. Aquino, health and education concern were given the priority and emphasis. It aims to extend education assistance to many Filipino children starting from preschool to secondary education by giving them daily allowances while pursuing their studies. Moreover, the parents are remarkably relieved from the exorbitant cost of tuition fees and other expenses borne in sending their children to school with the financial assistance provided through this program of the government including provision for dietary allowances to buy food for the children going to school.

For the proper implementation of the Pantawid program, the Department of Social Welfare and Development(DSWD) is the lead agency of the 4Ps which was patterned from the Conditional Cash Transfer system from identified developing countries. In its inception and early stages of implementation, there were various challenges and constraints expected to be encountered as the pilot program is considerably young and on its initial or beginning stage. However, accordingly, the government successfully rolled out the Pantawid Pamilya. Joint efforts and collaboration between and among the concerned line agencies and partner institutions in implementing the pilot program and establishing system for household targets were critical to the desired and target expansion of the program.

The operation of the 4Ps are widely distributed nationwide in the Philippines covering 79 provinces, 143 cities, and 1,484 municipalities. The government employed the National Household Targeting System for Poverty Reduction(NSTH-PR) in selecting the beneficiaries. It is used to screen and identify the poor families including their respective places in the country. The poorest among poor families as identified by 2003 Small Area Estimate(SAE) survey of the National Statistical Coordination Board(NSCB) are eligible. As provided, the target beneficiaries are chosen by way of a proxy-means test. Proxy variables served as indicators of the economic category of each family that includes assets ownership, type of housing, education of the head of the family, livelihood and access to water and sanitation. Included in the qualification of the beneficiary is the presence of children with age ranging from 0 to 4 as well as with pregnant women as of the assessment who shall agree to all the conditions set by the program.

The implementation and operation of the program is set to be monitored by the so-called municipal or city link including Barangay LGU, RHU and the Dep-Ed. Grantees are given an amount based on their compliance to the stated conditions set by the Pantawid program. Non compliance of said provision are accorded with corresponding penalty which may ultimately lead to dismissal if offences are repeated or done frequently.

Areas of monitoring includes mostly the health condition of children aged 2-5 and education with ages ranging from 3-14 years old as well as attendance to FDS being done bi-monthly. As to the health condition, the monitoring is done by a team that is composed of the doctor, nurse or midwife and the Municipal Link(ML) and Parent Leader(PL). On the otherhand, compliance on conditions set for education includes the principal or teacher. Accordingly, the ML visits the school and its health facilities every after two months to likewise collect the compliance verification(cv) report as accomplished. Such report will be used as basis for the cash grant to be awarded to the respective family(Pantawid Pamilya Guide Booklet)

Conceptual Framework

Consistently identified as pervasive perennial problem besetting most particularly the third world countries including the Philippines is poverty. Records unveil the continues struggle of man for existence and survival amidst the invasion of modernization characterized by dynamic innovation and technology. Cost of living soar high unceasingly bringing much hardships and difficulties to life. To a common Filipino family, the meagre income of the household mostly on the threshold level are hardly enough to sustain and maintain a decent living for each of the members considering the different needs of everyone. The economic pyramid clearly shows the largest segment of the population below the poverty line. Most of the income derived are hardly sufficient to provide even for the basic needs of the family including food and clothings with a very thin slice for health and education. 
Relatively, the problem of poverty was consistently identified the main reason for malnutrition, poor health and susceptibility to diseases specially the children. In like manner, low income of the family is likewise considered the main reason for thousands of Filipinos for their failure and even frustration to graduate even with a basic education and much more, to finish a course. This national problem directly affecting the citizens of the country snatched the attention of no less than the president of the state into a level of full alarm thereby initiating an intervention to address the increasing problem of poverty in the country. Guided by the doctrine that is, "Health citizen builds healthy nation" the government created the poverty alleviation program particularly the Pantawid Pamilyang Pilipino Program with its special features and attributes.

An old belief somehow pervade many individuals such that, poverty begets poverty. Children descending from poor and the marginal sector of the society so they claim are most likely to remain poor for the rest of their lives except for exceptional few who struggled to free themselves and run from the sting of economic scarcity or those fewer than few who, along the road found good fate from nowhere. These belief are anchored on the fact that financially incapacitated underprivileged parents can hardly provide for the education and other physical needs of their children with the economic limitations and constraints they live with. These provisions should pave way for these children the opportunity to better their lives in the different aspects including economic, financial and social only if afforded to the young sufficiently and substantially.

As disclosed, "Pantawid Pamilyang Pilipino Program(4Ps) is a guide to, a guard and a teacher's aide, rolled into one with the program's conditions of having an 85\% monthly attendance to all school children 6-14 years old. With the very favourable provision to the family, the parents themselves, as expected exert more effort manifesting interest being the ones prodding their children to attend all their classes in perfect attendance. As observed further, the parents actively involve themselves in the studies of their children giving them some time for tutorial activities at home with further coaching on the lessons given by their teachers. Also, parents showed more enthusiasm in the learning process of their children helping them review their lessons and also in making their homework and assignments.

Simultaneous with the provision of health and education benefits to the children, the Program likewise extend education to the parents through adult learning. Relevant seminars are conducted among the parents such as parenting-effectiveness seminar, family planning, nutritional classes, housekeeping, child-rearing and other topics aimed at educating the parents building more of their potentials and capability.

In its context, Pantawid as the term implies, signifies crossing or traversing a hardly favourable social and economic situation with an objective of helping the beneficiaries enable themselves to achieve a better life by giving them opportunity to elevate their economic situation to a higher level from their present status and condition. Instituted as a countrywide strategy to address the increasing problem of poverty, this research is proposed to assess the implementation of the government program particularly among beneficiaries among selected barangays of Tabuk as originally designed and conceptualized.

The conceptual paradigm of the study in figure 1 presents the Pantawid Pamilyang Pilipino Program and its socioeconomic impact among the beneficiaries/grantees from the selected barangays of Tabuk. 


\begin{tabular}{|c|c|}
\hline INDEPENDENT VARIABLES & DEPENDENT VARIABLE \\
\hline $\begin{array}{l}\text { 1. } \text { Demographic profile of the } \\
\text { respondents along: } \\
\text { - } \text { Age } \\
\text { - } \text { Gender } \\
\text { - } \quad \text { Nivil } \\
\text { - } \text { Occupation } \\
\text { - } \quad \text { Educational attainment } \\
\text { - } \quad \text { Ethnic affiliation } \\
\text { - } \quad \text { Number of children aged 2-14 } \\
\text { 2. } \text { Household Size } \\
\text { objectives of 4Ps among the } \\
\text { selected barangays of Tabuk } \\
\text { Extent of impact of Pantawid } \\
\text { Pamilyang Pilipino Program to the } \\
\text { living standard of the beneficiaries. } \\
\text { 4. Constraints affecting the } \\
\text { implementation of the program }\end{array}$ & $\begin{array}{l}\text { Pantawid Pamilyang Pilipino } \\
\text { Program(4Ps) and Its Socio- } \\
\text { Economic Impact to the Living } \\
\text { Standard of the Beneficiaries Among } \\
\text { the Selected Barangays of Tabuk }\end{array}$ \\
\hline
\end{tabular}

The study assessed the Pantawid Pamilyang Pilipino Program(4Ps) and its socio-economic impact to the living standard of the beneficiaries from selected barangays of Tabuk. Specifically, it focused on the following objectives:

To identify the demographic and economic profile of the respondents along:

1. Age

2. Gender

3. Civil

4. Number of Children

5. Occupation

6. Educational attainment

7. Ethnic affiliation

8. Household size

To determine the level of attainment of goals and objectives of the Pantawid Pamilyang Pilipino Programs(4Ps) among beneficiaries from selected barangays of Tabuk.

To identify the extent of impact of Pantawid Pamilyang Pilipino Program to the living standard of the beneficiaries.

To determine the extent of constraints affecting the implementation of the Program.

\section{Significance of the Study}

The output of the study shall bear significance to the following:

Program Beneficiaries. As the identified grantees and beneficiaries of the program, the results of the study shall be a concrete proof and evidence of the willingness and sincerity of the government to bring its arms to them in basically addressing the increasing problem of poverty which is directly affecting them.

Barangay officials and the community. Results of the study will generate data and information showing the partnership of the barangay officials together with the community particularly in their receptivity and commitment to work with the national government on programs and projects that seek to uplift the living condition and standards specially those in the marginalized sector. 
DSWD and other Line agencies. Results of the study may serve as feedback mechanism and may be used as one among the vital tools in an objective assessment and evaluation of the program specially on its effectiveness and reliability as contained in its goals and objectives.

Parents. The study shall serve both as an eye-opener and reinforcement on the extent of assistance the national government is extending to them with its concern to provide initiative and extend subsidies just so to help them elevate their current financial and economic situation into a higher level onwards a better living.

Researcher. As a concern citizen and at the same a government employee, the study in itself will be very significant as she takes part in the direct independent and actual assessment on how the government bring itself to the target poor families to work directly with them to traverse the pervading problem of poverty causing much incapacity and limitation on their ways towards life improvement starting basically in their health and children's education. Eventually, the study may develop government goodwill of which the researcher is an employee.

Students. The students will likewise find significance on the result of this study with the information being derived on how the government work through program and projects to uplift the living condition of its citizens. As students, they need to be informed on how the government conceive and implement programs that seek to address problems affecting its citizens.

Future Researchers. Researchers with future endeavours that are similar or related either whole or partial may find the study relevant with its concepts, processes conducted and the eventual findings.

Scope and delimitation of the Study

The study looked into the level of implementation of the Pantawid Pamilyang Pilipino Program(4Ps) in selected barangays of Tabuk looking further on its socio and economic 1. Paradigm of the Study impact on the living standard of the beneficiaries/grantees.

\section{Review of Literature}

The program was renamed as Pantawid Pamilyang Program(4Ps) on July 16, 2008 by Samantha A. Vizconde with the issuance of administrative order number 16, series of 2008 upon which the implementing guidelines were set (Longan,2016). It is a health and education program of the administration by then President Noynoy Aquino. It aims to educate many Filipino children starting from preschool to secondary education by way of providing school allowances. Likewise, parents of these children undergo formal education as extended by the government covering topics health on basic health, child-rearing, proper nutrition and others.

With the reports provided by the Department of Social Welfare and Development(DSWD) which is the lead government agency on this program, the 4Ps is being operated nationwide covering a total of 79 provinces, 143 cities and 1,484 municipalities. Accordingly, the beneficiaries are selected through the National Household Targeting System for Poverty Reduction(NSTH-PR), which identifies who and where do the poor families reside in the country. The poorest among the poor families are identified by 2003 Small Area Estimate(SAE) survey of National Statistical Coordination Board(NSCB) are eligible. The poorest among the poor are selected through a proxy-means test. Economic indicators such as ownership of assets, type of housing, education of the heads of the families, livelihood of the family, access to water and sanitation facilities are proxy variables to indicate the family economic category.

As stated in the Pantawid Pamilya Guide Booklet, the Pantawid program is being monitored jointly by the municipal link, BLGU, RHU and Dep-Ed. Relatively, beneficiary-compliance to the given conditions will serve as the basis for the amount to be given to the grantees. Non compliance to one or more of the provisions/conditions is given a corresponding sanctions or penalties and to extreme cases may lead to dismissal from the program.

Monitoring activities particularly on education of children with ages 3-14, health condition with ages 2-5 and attendance to FDS is being done bi-monthly. The monitoring team including the doctor, nurse or midwife including the Municipal Link(ML) and Parent Leader(PL) monitors the compliance on the health conditions of the beneficiaries. Furthermore, the principal or the teacher monitors the compliance on education as received by the children. The ML visits the school and health facilities within the municipality every after two months to collect 
the compliance verification(CV) form indicating the obedience and compliance to the conditions of the program. The individual records will be the basis for ascertaining and releasing the amount to the family.

In a related search, Mayo(2006) discloses identified causes of poverty in the United States such as economic factors characterized by high unemployment rate, job scarcity, lack of skilled workers and discrimination. This particular condition is disproportionately noted in minority group members and families headed by women; cultural factors such that, the poor have difficulty in entering the mainstream of the society and political factors caused by society which is unequal in the distribution of income, interest and power.

During the administration of President Gloria Macapagal Aroyo, alleviation of poverty(Palino an Canao,2015) was one among the ten-points agenda of the government which eventually led the conceptualization and ultimately, the implementation of the program with the target beneficiaries. The sincere effort of the government to this concern address the nutrition needs of the school children. During recess time, the children beneficiaries are regularly fed with nutritious food being prepared intentionally for them with the funds coming from the government. The program firmly believes the necessity of giving nutritious diet to growing school children for them to grow healthy both body and mind. Basically, a healthy mind allows better comprehension and understanding among the learners.

\section{Definition of Terms}

For a better understanding of the entire work, the following terms are defined as they are used particularly:

Beneficiary. This refers to the individuals being qualified as recipient of the benefits provided by the program.

Grantee. This word refers to the registered member under the program who is privileged and authorized to receive the allotted financial assistance.

Family Development Sessions(FDS). This refers to meeting or sessions conducted among the parents for the conduct of information drive, seminars, and trainings on topics related to family rearing and concerns.

Impact. This refers to the effect of degree of change in certain subject.

Household. Refers to the people in a family or other group that are living together in house.

Poverty. This refers to the state of being poor or lack of something.

Parent Leader(PL). This refers to parent-beneficiaries who are chosen to lead a cluster of parents and helps the municipal in implementing the program.

\section{Methodology:-}

Locale of the Study

The study will be conducted among the beneficiaries of 4Ps in the selected adjacent barangays of Tabuk including Casigayan, San Julian, Dilag, Laya and Balong.

\section{Research Design}

This research will employ both the descriptive method and documentary analysis with some interviews to be conducted inorder to validate data and clarify information as maybe necessary.

\section{Respondents/informants/research participants of the study}

Beneficiaries of the Pantawid Pamilyang Pilipino Program(4Ps) from the identified adjacent barangays of Tabuk are the respondents of the study. Additional information were likewise taken from the lead agency which is the DSWD as well the barangay local government unit.

\section{Instrumentation}

This research which is a descriptive type used a structured questionnaire as the main instrument to gather data and obtain essential information to satisfy the objectives set in this work. 


\section{Data Gathering}

Firstly, letters were sent to the respective barangay captains for the proper conduct of the research work in their respective areas. Eventually, research questionnaires administered personally among the identified beneficiaries using random sampling as basis of identifying and selecting the respondents.

\section{Data Analysis}

Both descriptive and inferential methods were employed analyze the data. Frequency count, percentage and weighted mean will be used to statistically treat the data.

\section{Treatment of Data}

With regards to the level of attainment of goals and objectives of the program and the extent of impact to the living standard of the beneficiaries, the following scales were be used:
Arbitrary Value
Limits
Descriptions
Symbols

5

4

3

2

1
$4.21-5.00$

$3.41-4.20$

$2.61-3.40$

$1.81-2.60$

$1.00-1.80$

\section{Very Much Attained VMA \\ Very High Impact $\quad$ VHI}

Much Attained MA

High Impact HI

Moderately Attained MoA

Moderately Impact MoI

Less Attained LA

Less Impact

Not Attained NA

No Impact NI

To assess the extent of constraints affecting the implementation of the program, the following scale will be used:

$\begin{array}{llll}5 & 4.21-5.00 & \text { Very Much Serious } & \text { VMS } \\ 4 & 3.41-4.20 & \text { Much Serious } & \text { MS } \\ 3 & 2.61-3.40 & \text { Moderately Serious } & \text { MoS } \\ 2 & 1.81-2.60 & \text { Less Serious } & \text { LS } \\ 1 & 1.00-1.80 & \text { Not Serious } & \text { NS }\end{array}$

Results and Discussion:-

This section presents the results and discussion of the study.

Table 1:-Demographic Profile of the Respondents as to Age, Gender, Civil Status, Number of Pregnant Women and Highest Educational Attainment

\begin{tabular}{|c|c|c|c|c|c|c|c|c|c|c|c|c|c|c|c|}
\hline & \multicolumn{2}{|l|}{ Age } & \multicolumn{2}{|c|}{ Gender } & \multirow[t]{2}{*}{ Pregnant } & \multicolumn{4}{|c|}{ Civil Status } & \multicolumn{6}{|c|}{ Highest Educational Attainment } \\
\hline $\begin{array}{l}\text { Age } \\
\text { Bracket }\end{array}$ & $\mathrm{F}$ & $\%$ & $\mathrm{~F}$ & $\mathrm{M}$ & & $\mathrm{S}$ & M & Sep & $\begin{array}{l}\text { W/ } \\
\text { Wdr }\end{array}$ & EL & EG & HSL & HSG & CL & CG \\
\hline $\begin{array}{l}18-25 \\
\text { Years }\end{array}$ & 32 & 23 & 28 & 4 & 16 & 4 & 17 & 0 & 0 & 2 & 6 & 4 & 7 & 1 & 1 \\
\hline $26-33$ & 44 & 32 & 39 & 5 & 28 & 7 & 23 & 2 & 4 & 4 & 8 & 7 & 13 & 4 & 0 \\
\hline $34-41$ & 38 & 27 & 10 & 28 & 3 & 8 & 29 & 1 & 13 & 7 & 6 & 16 & 20 & 1 & 1 \\
\hline $42-49$ & 17 & 12 & 6 & 11 & 1 & 2 & 5 & 8 & 5 & 4 & 5 & 5 & 4 & 0 & 2 \\
\hline $\begin{array}{l}50 \\
\text { above }\end{array}$ & 9 & 6 & 5 & 4 & 0 & 2 & 2 & 2 & 6 & 3 & 2 & 4 & 3 & 0 & 0 \\
\hline Total & 140 & & 88 & 52 & 48 & 23 & 76 & 13 & 28 & 20 & 27 & 36 & 47 & 6 & 4 \\
\hline $\begin{array}{l}\text { Percent } \\
\text { age }(\%)\end{array}$ & & 100 & 63 & 37 & 34 & 17 & 54 & 9 & 20 & 14 & 19 & 26 & 34 & 4 & 3 \\
\hline
\end{tabular}

Legend: EL- Elem Level, EG-Elem Graduate, HSL-High School Level , HSG-High School Graduate, CLCollege Level CG-College Graduate

There were 140 total respondents of the study from the identified barangays of Tabuk city of which the female group are higher in number representing $63 \%$ of the population. As clearly specified in the manual of operations for the Pantawid Program, 48 pregnant women were included. Expectedly, married individuals composed most of 
the population with some who are single, separated and widow/widower. There is a relatively low level of educational attainment with the highest number of respondents being high school graduate, high school level, elementary graduate and elementary level. A mere $7 \%$ have reached or finished college education.

Carlos P. Romulo is quoted saying, "An educated and well-informed citizen makes a powerful nation" and further affirmed with preaching of the elderly saying, education counters and travers poverty- clearly define the findings of the study in part or in whole. Low level of education somehow limits the access of people to helpful information, methods and even programs from all sources, either from government and private entities. and more so, they could hardly equip themselves on the rigors and arms for a better if not best life. Such principle accords one of the best teachings of the old school particularly on development: Do not give people fish but rather teach the people to fish.

Table 2:-Demographic Profile on Ethnic Affiliation and Occupation of the Respondents

\begin{tabular}{|l|l|l|l|l|l|l|l|l|}
\hline Ethnic Affiliation & \multicolumn{9}{l|}{ Occupation } & Hedper \\
\hline Ethnic Groupings & Fqcy & $\%$ & Housekeeping & Farming & $\begin{array}{l}\text { Hired } \\
\text { Labor }\end{array}$ & $\begin{array}{l}\text { Small } \\
\text { Business }\end{array}$ & Helper \\
\hline Bago Tribe & 15 & 11 & 12 & 3 & 9 & 6 & 2 \\
\hline Igorot & 10 & 07 & 6 & 4 & 4 & 5 & 5 & \\
\hline Ilocano & 43 & 31 & 18 & 20 & 3 & 3 & 5 \\
\hline Kalinga & 37 & 26 & 23 & 22 & 5 & 2 & 3 \\
\hline Muslim & 14 & 10 & 10 & 4 & 0 & 13 & 0 \\
\hline Tagalog & 21 & 15 & 19 & 0 & 5 & 3 & 4 \\
\hline Total & 140 & & 88 & 49 & 26 & 32 & 19 \\
\hline Percentage & & 100 & 63 & 35 & 19 & 23 & 14 \\
\hline
\end{tabular}

The highest number of respondents are the Ilocano who are the major constituents of the said barangays followed by the Kalinga and Tagalog group. Further shown that almost all of the tribes inhabiting the identified places are recipients and beneficiaries of the government program.

As expected, all the female respondents with a total of 88 do housekeeping who are likewise devoted in doing household chores and other daily routines and activities for the family. Doing plain housekeeping does not usher any single centavo income for the family. Other occupations of small percentage include farming, operation of small business such as sari-sari store, rolling vendor and house-to-house selling with the least obtained result on hired labor.

Apparently, there is the sharp fall of hired/manual labor available in the area. Having grown in one of the identified area, since time immemorial observed the very good supply or availability of manual labor in the areas including carpentry, masonry, manual hauling, pay labor for farm and other house work. In fact, for decades or even centuries, people would constantly avail and involved themselves in manual labor either in group or individual with the noble and historic toil of planting and harvesting rice, corn, coffee, fruits and vegetables. As a matter of practice, members of the family specially those unable to finish a college course would go house to house in order to hunt available job or work for them to raise income considering the growing family size with a more increasing needs and demand for living including education for children.

In a written article, Albano(2018) is quoted particularly with his paper entitled, "4 Ps induces indolence?" . Accordingly, there is a dearth of farm labor specially in days following the 4Ps payout. Luis Aoas, a Lutheran pastor and a leader of the Basao tribe, related that before the advent of the 4Ps in the locality he had no trouble with farm labor as his tribesmates would even go to his house to ask him if he has work for them to do but these days, he has to go around the two Basao villages in the city to seek workers at times in vain. He said that situation is the same in their ancestral village in Tinglayan municipality where some of the rice paddies are left to fallow due to the shortage of people wanting to labor in the mud after the introduction of the 4Ps.

Table 3:-Size of Household/Number of Family Members Living Together in the House

\begin{tabular}{|l|l|l|}
\hline Number of Family Members & Number of Households \\
\hline & Frequency & Percentage \\
\hline $1-3$ & 16 & 11.43 \\
\hline
\end{tabular}




\begin{tabular}{|l|l|l|}
\hline $4-6$ & 39 & 27.86 \\
\hline $7-9$ & 56 & 40.00 \\
\hline 10 and above & 29 & 20.71 \\
\hline Total & 140 & 100 \\
\hline
\end{tabular}

The highest enlisted number of 56 households have a family size of 7-9 family members living in the house, followed by those with 4-6; 10 and above and the least frequency are with 1-3 members of the family. Generally, the households have a large size of families to sustain. Relatively, considering the occupation which are mostly seasonal with no fixed rate of income at any given period, difficulty brought by meagre family income characterized the living condition of the families. Supposedly, such condition should encourage and even oblige the members to go into more livelihood activities to support even just the basic needs of the family but this study found the opposite with the advent of free financial provision from the Program.

Table 4:-Number of Children Attending School

\begin{tabular}{|l|l|l|}
\hline Grade Level & Frequency & Percentage \\
\hline Pre-school & 94 & 16.79 \\
\hline Elementary & 261 & 46.61 \\
\hline Secondary & 205 & 36.61 \\
\hline TOTAL & $\mathbf{5 6 0}$ & $\mathbf{1 0 0 . 0 0}$ \\
\hline
\end{tabular}

There are 560 children of the beneficiary households who are attending school at different grade levels starting from pre-school, elementary and secondary with the majority at elementary level. An average of 4 children per household who are benefited by the Program including their education.

The next section presents the extent of assessment by the beneficiaries and other identified respondents on the extent of attainment of goals and objectives; extent of impact and the extent of constraints affecting the implementation of the Program in Tabuk city.

Table 5:-Attainment of Goals and Objectives

\begin{tabular}{|c|c|c|c|c|c|c|}
\hline Indicators & $\begin{array}{l}\text { VMA } \\
(5)\end{array}$ & $\begin{array}{l}\text { MA } \\
(4)\end{array}$ & $\begin{array}{l}\text { MoA } \\
\text { (3) }\end{array}$ & $\begin{array}{l}\text { LA } \\
(2)\end{array}$ & $\begin{array}{l}\text { NA } \\
(1)\end{array}$ & Mean \\
\hline $\begin{array}{l}\text { 1. Increased participation in community and social } \\
\text { activity. }\end{array}$ & $\begin{array}{l}11 \\
(55)\end{array}$ & $\begin{array}{l}53 \\
(212)\end{array}$ & $\begin{array}{l}59 \\
(177)\end{array}$ & $\begin{array}{l}17 \\
(34)\end{array}$ & $\begin{array}{l}0 \\
(0)\end{array}$ & 3.41 \\
\hline $\begin{array}{l}\text { 2. Enhanced knowledge and skills on different } \\
\text { services/programs of the government and as } \\
\text { beneficiaries and as parents. }\end{array}$ & $\begin{array}{l}20 \\
(100)\end{array}$ & $\begin{array}{l}56 \\
(224)\end{array}$ & $\begin{array}{l}28 \\
(84)\end{array}$ & $\begin{array}{l}26 \\
(52)\end{array}$ & $\begin{array}{l}10 \\
(10)\end{array}$ & 3.36 \\
\hline 3. Improved health condition. & $\begin{array}{l}5 \\
(25)\end{array}$ & $\begin{array}{l}61 \\
(244)\end{array}$ & $\begin{array}{l}48 \\
(144)\end{array}$ & $\begin{array}{l}16 \\
(32)\end{array}$ & $\begin{array}{l}10 \\
(10)\end{array}$ & 3.25 \\
\hline 4. Improved literacy rate. & $\begin{array}{l}18 \\
(90)\end{array}$ & $\begin{array}{l}57 \\
(228)\end{array}$ & $\begin{array}{l}31 \\
(93)\end{array}$ & $\begin{array}{l}18 \\
(36)\end{array}$ & $\begin{array}{l}16 \\
(16)\end{array}$ & 3.31 \\
\hline 5. Social amelioration. & $\begin{array}{l}4 \\
(20)\end{array}$ & $\begin{array}{l}49 \\
(196)\end{array}$ & $\begin{array}{l}28 \\
(84)\end{array}$ & $\begin{array}{l}31 \\
(62)\end{array}$ & $\begin{array}{l}28 \\
(28)\end{array}$ & 2.79 \\
\hline 6. Increased people's confidence in the government. & $\begin{array}{l}20 \\
(100)\end{array}$ & $\begin{array}{l}41 \\
(64)\end{array}$ & $\begin{array}{l}33 \\
(99)\end{array}$ & $\begin{array}{l}26 \\
(52)\end{array}$ & $\begin{array}{l}20 \\
(20)\end{array}$ & 3.11 \\
\hline 7. Increased social responsibility. & $\begin{array}{l}3 \\
(15)\end{array}$ & $\begin{array}{l}11 \\
(44)\end{array}$ & $\begin{array}{l}37 \\
(111)\end{array}$ & $\begin{array}{l}41 \\
(82)\end{array}$ & $\begin{array}{l}48 \\
(48)\end{array}$ & 2.14 \\
\hline 8. Economic sustainability & $\begin{array}{l}4 \\
(20)\end{array}$ & $\begin{array}{l}15 \\
(60)\end{array}$ & $\begin{array}{l}18 \\
(54)\end{array}$ & $\begin{array}{l}48 \\
(96)\end{array}$ & $\begin{array}{l}55 \\
(55)\end{array}$ & 2.04 \\
\hline 9. Better future. & $\begin{array}{l}6 \\
(30)\end{array}$ & $\begin{array}{l}27 \\
(108) \\
\end{array}$ & $\begin{array}{l}21 \\
(63) \\
\end{array}$ & $\begin{array}{l}29 \\
(58)\end{array}$ & $\begin{array}{l}57 \\
(57)\end{array}$ & 2.26 \\
\hline 10. Improved family income. & $\begin{array}{l}41 \\
(205)\end{array}$ & $\begin{array}{l}48 \\
(96)\end{array}$ & $\begin{array}{l}33 \\
(99)\end{array}$ & $\begin{array}{l}12 \\
(24)\end{array}$ & $\begin{array}{l}6 \\
(6)\end{array}$ & 3.07 \\
\hline AWM & & & & & 2.87 & \\
\hline
\end{tabular}


The respondents assessed the attainment of the goals and objectives of the Program as moderate with a total average weighted mean of 2.87. Furthermore, there is a relatively low level of attainment of the goals and objectives as revealed in the individual assessment of the identified goals and objectives.

Meanwhile, the highest assessment is particularly on the objective, Increased participation in community and social activity of 3.41 described as much attained while the least assessment was accorded particularly on, Economic sustainability with mean result of 2.04 or less attained. The standard procedure included in the program is the strict attendance to the different activities and programs as part of proper implementation. Taken more as mandate and compulsory with the religious checking of attendance on participating, hence, the result.

Economic sustainability was with the least result being assessed as less attained. Earlier findings of this study reasonably reflected the actual scenario, negative and unproductive attitudes mostly of the beneficiaries characterized by some sort of abuses, indolence and hostility. Many of the households resorted to negative characters and attitudes instead of upholding and complementing the program for their welfare. Reports and observation shows the indolence of many members mostly depending on their regular pay-outs. In the absence of proper concern, enhancement and individual complementation, the program can hardly assume and sustain economic sustainability.

The following shows the assessment of the respondents on the extent of impact of the program.

Table 6:-Extent of Impact of the Program

\begin{tabular}{|c|c|c|c|c|c|c|}
\hline B. INDICATORS & $\begin{array}{l}\text { VMI } \\
(5)\end{array}$ & $\begin{array}{l}\mathrm{MI} \\
(4)\end{array}$ & $\begin{array}{l}\text { MoI } \\
\text { (3) }\end{array}$ & $\begin{array}{l}\text { LI } \\
(2)\end{array}$ & $\begin{array}{l}\text { NI } \\
(1)\end{array}$ & Mean \\
\hline $\begin{array}{l}\text { 1. Improved preventive health care among } \\
\text { pregnant women and young children. }\end{array}$ & $\begin{array}{l}11 \\
(55)\end{array}$ & $\begin{array}{l}28 \\
(112)\end{array}$ & $\begin{array}{l}49 \\
(147)\end{array}$ & $\begin{array}{l}46 \\
(92)\end{array}$ & $\begin{array}{l}6 \\
(6)\end{array}$ & 2.94 \\
\hline $\begin{array}{l}\text { 2. Increase the enrolment and attendance rate of } \\
\text { children in school. }\end{array}$ & $\begin{array}{l}14 \\
(70)\end{array}$ & $\begin{array}{l}53 \\
(212)\end{array}$ & $\begin{array}{l}38 \\
(114)\end{array}$ & $\begin{array}{l}25 \\
(50)\end{array}$ & $\begin{array}{l}10 \\
(10)\end{array}$ & 3.26 \\
\hline 3. Reduce the incidence of child labor. & $\begin{array}{l}13 \\
(65)\end{array}$ & $\begin{array}{l}59 \\
(236)\end{array}$ & $\begin{array}{l}42 \\
(126)\end{array}$ & $\begin{array}{l}20 \\
(40)\end{array}$ & $\begin{array}{l}6 \\
6)\end{array}$ & 3.38 \\
\hline $\begin{array}{l}\text { 4. Raise the average consumption rate in food } \\
\text { expenditure of poor households. }\end{array}$ & $\begin{array}{l}7 \\
(35)\end{array}$ & $\begin{array}{l}39 \\
(156)\end{array}$ & $\begin{array}{l}38 \\
(114)\end{array}$ & $\begin{array}{l}36 \\
(72)\end{array}$ & $\begin{array}{l}20 \\
(20)\end{array}$ & 2.84 \\
\hline $\begin{array}{l}\text { 5. Parents to invest in their children's(and their } \\
\text { own) human capital through investments in } \\
\text { their health, nutrition, education and } \\
\text { participation in community activities. }\end{array}$ & $\begin{array}{l}5 \\
(25)\end{array}$ & $\begin{array}{l}38 \\
(152)\end{array}$ & $\begin{array}{l}21 \\
(63)\end{array}$ & $\begin{array}{l}27 \\
(54)\end{array}$ & $\begin{array}{l}49 \\
(49)\end{array}$ & 2.45 \\
\hline $\begin{array}{l}\text { 6. Enhance and strengthen the parenting education } \\
\text { skills and knowledge of parents. }\end{array}$ & $\begin{array}{l}11 \\
(55)\end{array}$ & $\begin{array}{l}41 \\
(164)\end{array}$ & $\begin{array}{l}31 \\
(93)\end{array}$ & $\begin{array}{l}38 \\
(76)\end{array}$ & $\begin{array}{l}19 \\
(19)\end{array}$ & 2.91 \\
\hline $\begin{array}{l}\text { 7. Help the children achieve their developmental } \\
\text { needs particularly on health and education. }\end{array}$ & $\begin{array}{l}14 \\
(70)\end{array}$ & $\begin{array}{l}30 \\
(120)\end{array}$ & $\begin{array}{l}41 \\
(123)\end{array}$ & $\begin{array}{l}34 \\
(68)\end{array}$ & $\begin{array}{l}21 \\
(21)\end{array}$ & 2.87 \\
\hline $\begin{array}{l}\text { 8. Help parents appreciate compliance with the } \\
\text { health and education conditions of the program. }\end{array}$ & $\begin{array}{l}13 \\
(65)\end{array}$ & $\begin{array}{l}41 \\
(164)\end{array}$ & $\begin{array}{l}40 \\
(120)\end{array}$ & $\begin{array}{l}29 \\
(58)\end{array}$ & $\begin{array}{l}17 \\
(17)\end{array}$ & 3.03 \\
\hline $\begin{array}{l}\text { 9. Alleviate poverty in the short-run, while raising } \\
\text { the human capital of poor beneficiaries. }\end{array}$ & $\begin{array}{l}2 \\
(10)\end{array}$ & $\begin{array}{l}11 \\
(44)\end{array}$ & $\begin{array}{l}32 \\
(96)\end{array}$ & $\begin{array}{l}49 \\
(98)\end{array}$ & $\begin{array}{l}46 \\
(46)\end{array}$ & 2.10 \\
\hline $\begin{array}{l}\text { 10. Update/inform beneficiaries of new } \\
\text { guidelines/policies/programs services of the } \\
\text { government likewise resolve issues/concerns } \\
\text { through their family development session. }\end{array}$ & $\begin{array}{l}25 \\
(125)\end{array}$ & $\begin{array}{l}39 \\
(156)\end{array}$ & $\begin{array}{l}30 \\
(90)\end{array}$ & $\begin{array}{l}28 \\
(56)\end{array}$ & $\begin{array}{l}18 \\
(18)\end{array}$ & 3.18 \\
\hline AWM & \multicolumn{6}{|c|}{2.90} \\
\hline
\end{tabular}

The Program have a moderate impact on the households with obtained average weighted mean of 2.90. Relatively the highest assessments were recorded along, reduce the incidence of child labor and increase the enrolment and attendance rate of children in school of 3.38 and 3.26 both described as moderately impact. Apparently, parents enrolled their children for them to avail of the financial support extended by the government through the Program. Consequently, in as much that the children are strictly enrolled by their parents to respective schools, they are 
strictly confined within the school to attend classes instead of rendering labor for a fee in the locality. These particular results somehow satisfy in part the objective of the Program even in its conceptualization to its actual implementation.

To the opposite, the lowest impact of 2.10 is assessed on the particular impact, alleviate poverty in the short-run, while raising the human capital of poor beneficiaries.

While it is true that there is there is the literal infusion of cold cash to it variable amount to the households, there is that immediate impact of increasing money that in a way have alleviated poverty on the spot by with the remaining indicator that is, raising the human capital of the poor families was adversely unveiled.

The earlier and aforementioned results and findings revealed the negative turn of most of the members into indolence and other negative attitudes along side the benefit extended to them. Also, instead of complementing the provision extended through the Program, a lot of members recreate themselves into leech merely sucking the funds of the government raised from the bloody taxes of the paying-individuals. "Instead of treating the Pantawid grant as a supplement, generally speaking, it is now the main reason my tribesmates are losing their desire to work. The program is eroding the value of hard work and has created the taste for the easy life. I speak for my tribe," Aoas said as quoted by Albano(2018).

The last section reveals the extent of constraints affecting the implementation of the Pantawid Pamilyang Pilipino Program(4Ps) in Tabuk city.

Table 7:-Extent of Constrains Affecting the Implementation of the Program(N=250)

\begin{tabular}{|c|c|c|c|c|c|c|}
\hline CONSTRAINTS INDICATORS & $\begin{array}{l}\text { VMS } \\
(5)\end{array}$ & $\begin{array}{l}\mathrm{MS} \\
(4)\end{array}$ & $\begin{array}{l}\mathrm{MoS} \\
(3)\end{array}$ & $\begin{array}{l}\text { LS } \\
(2)\end{array}$ & $\begin{array}{l}\mathrm{NS} \\
(1)\end{array}$ & Mean \\
\hline $\begin{array}{l}\text { 1. Members use ATM/Cash card as collateral to borrow } \\
\text { money from private/individual money lenders }\end{array}$ & $\begin{array}{l}92 \\
(460)\end{array}$ & $\begin{array}{l}141 \\
(564)\end{array}$ & $\begin{array}{l}8 \\
(24)\end{array}$ & $\begin{array}{l}9 \\
(18)\end{array}$ & $\begin{array}{l}0 \\
(0)\end{array}$ & 4.26 \\
\hline $\begin{array}{l}\text { 2.Some members of this program are becoming lazy to } \\
\text { work in their fields or on labor basis because they are } \\
\text { dependents on the cash grant that they receive. }\end{array}$ & $\begin{array}{l}96 \\
(480)\end{array}$ & $\begin{array}{l}120 \\
(480)\end{array}$ & $\begin{array}{l}33 \\
(99)\end{array}$ & $\begin{array}{l}1 \\
(2)\end{array}$ & $\begin{array}{l}0 \\
(0)\end{array}$ & 4.24 \\
\hline $\begin{array}{l}\text { 3. Some parents who are members of this program are } \\
\text { buying accessories for themselves which is supposed to } \\
\text { be for the education of the children. }\end{array}$ & $\begin{array}{l}75 \\
(375)\end{array}$ & $\begin{array}{l}86 \\
(344)\end{array}$ & $\begin{array}{l}71 \\
(213)\end{array}$ & $\begin{array}{l}12 \\
(24)\end{array}$ & $\begin{array}{l}6 \\
(6)\end{array}$ & 3.85 \\
\hline $\begin{array}{l}\text { 4. Most of the members do not understand the concept of } \\
\text { this program. }\end{array}$ & $\begin{array}{l}62 \\
(310)\end{array}$ & $\begin{array}{l}88 \\
(352)\end{array}$ & $\begin{array}{l}80 \\
(240)\end{array}$ & $\begin{array}{l}20 \\
(40)\end{array}$ & $\begin{array}{l}0 \\
(0)\end{array}$ & 3.77 \\
\hline $\begin{array}{l}\text { 5. Some beneficiaries lend their cash grant to other people } \\
\text { with interest. }\end{array}$ & $\begin{array}{l}73 \\
(365)\end{array}$ & $\begin{array}{l}72 \\
(288)\end{array}$ & $\begin{array}{l}68 \\
(204)\end{array}$ & $\begin{array}{l}37 \\
(74)\end{array}$ & $\begin{array}{l}0 \\
(0)\end{array}$ & 3.72 \\
\hline $\begin{array}{l}\text { 6. There are those selected beneficiaries who do not } \\
\text { really qualify to the requirements of the program specially } \\
\text { that "poorest of the poor" while some of the real poor } \\
\text { are not chosen. }\end{array}$ & $\begin{array}{l}53 \\
(265)\end{array}$ & $\begin{array}{l}69 \\
(276)\end{array}$ & $\begin{array}{l}58 \\
(174)\end{array}$ & $\begin{array}{l}65 \\
(130)\end{array}$ & $\begin{array}{l}5 \\
(5)\end{array}$ & 3.40 \\
\hline $\begin{array}{l}\text { 7. Other members of this program will lash out at others } \\
\text { out of envy. }\end{array}$ & $\begin{array}{l}48 \\
(240)\end{array}$ & $\begin{array}{ll}51 \\
(204)\end{array}$ & $\begin{array}{l}79 \\
(237)\end{array}$ & $\begin{array}{l}69 \\
(138) \\
\end{array}$ & $\begin{array}{l}3 \\
(3)\end{array}$ & 3.29 \\
\hline 8. Negative attitude of residents & $\begin{array}{l}40 \\
(200)\end{array}$ & $\begin{array}{l}65 \\
(260)\end{array}$ & $\begin{array}{l}63 \\
(189)\end{array}$ & $\begin{array}{l}59 \\
(118)\end{array}$ & $\begin{array}{l}23 \\
(23)\end{array}$ & 3.16 \\
\hline 9 Using 4Ps for vote buying and for political interest. & $\begin{array}{l}49 \\
(245)\end{array}$ & $\begin{array}{l}58 \\
(232)\end{array}$ & $\begin{array}{l}52 \\
(156)\end{array}$ & $\begin{array}{l}62 \\
(124) \\
\end{array}$ & $\begin{array}{l}29 \\
(29)\end{array}$ & 3.14 \\
\hline $\begin{array}{l}\text { 10. Poor coordination between barangay executives and } \\
\text { residents }\end{array}$ & $\begin{array}{l}35 \\
(175)\end{array}$ & $\begin{array}{l}56 \\
(224)\end{array}$ & $\begin{array}{l}70 \\
(210)\end{array}$ & $\begin{array}{l}81 \\
(162)\end{array}$ & $\begin{array}{l}8 \\
(8)\end{array}$ & 3.12 \\
\hline 11. Crab mentality of some people & $\begin{array}{l}50 \\
(250)\end{array}$ & $\begin{array}{l}41 \\
(164)\end{array}$ & $\begin{array}{l}69 \\
(207)\end{array}$ & $\begin{array}{l}58 \\
(116)\end{array}$ & $\begin{array}{l}32 \\
(32)\end{array}$ & 3.08 \\
\hline AWM & \multicolumn{6}{|c|}{3.59} \\
\hline
\end{tabular}


The identified constraints have affected implementation of the Program to a much serious extent with most of the individual indicators assessed as either very much or much serious. Such over-all and individual results dispelled the not-so commendable mode of poverty alleviation when taken in its total perspective. In its truest sense, the Program has a very noble and human objective. Originally, it is designed to be a general mitigating intervention to the increasing pervasive problem of poverty nationwide but such conviction was not carried consistently along its implementation.

Equally disturbing and disgusting were the assessments on constraints, members use ATM/Cash card as collateral to borrow money from private/individual money lenders and, some members of this program are becoming lazy to work in their fields or on labor basis because they are dependents on the cash grant that they receive of 4.26 and 4.24 respectively both described as very much serious.

Relatively, some respondents have abused the main purpose of the Program being extended to them adversely doing the opposite. As intended, the Program in its proper implementation provide assistance that is meant to alleviate poverty but as shown with the results, it was maliciously taken as support to indolence leading to a graver poverty with the character and values of the members turned in reverse. Instead of exerting effort being inspired and secured with the fact that a regular fix assistance is given them absolutely free without thinking of any payment or return, they become idle and even a burden to the national economy.

As sited by Albano(2018), Adolph Bravo, vice president of the Upper Chico River Irrigation System Tabuk Pinukpuk Federation of Irrigators' Associations, alleges that the 4Ps is one of the three major reasons farm labor is no longer readily available all year round in the city the other two being the diminution of farm worker ranks due to ageing and the lure of greener pasture among the youth. "When they receive their grants, they wear their shoes and no longer want to step on the dikes. They do not feel the need to work until their 4Ps grant runs out," Bravo said in Ilocano(Albano,2018).

Further cited, Marilyn Pecua, principal of the Dilag Integrated School(DIS) in barangay Dilag, this city, reconciles the seeming contradiction by explaining that the spell of idleness strikes the beneficiaries after they withdraw their grants and will last until they spend the entire amount. Evangeline Licudo, leader of one of the seven kabisilyas or farm service provider teams in barangay Dilag, said that some 4Ps grantees no longer go to work when they hear of the payout. She said that when called to go to work, the grantees would say they have something to do but the truth is they will idle. "Instead of adding to the assistance, they depend on it until it's consumed," Licudo said in the vernacular. Licudo said they also observe the same phenomenon in Cauayan City, Isabela where their kabisilya sometimes go to plant or harvest rice.

Another disgusting and embarrassing result are the hostile and ungrateful practices of some members who makes careless borrowing to private loan sharks or usurers in the locality using their cashcard or ATM cards as collateral. Reports showed and actual observation at many counts where one or two individuals making a lot of withdrawals on atm machine in town with thick piles of cashcards for an hour or more causing much delay and inconvenience to other clients. Instead of teaching and developing wise spending, thrift and savings, among the members, they resorted to careless borrowing and spending. Abibico, as further related by Albano(2018) said that for one, the instances of loan sharks taking advantage of 4Ps beneficiaries could be eliminated of minimized through continuous monitoring. He related that at one time the ATM queue he was in was held up for around an hour by a woman who was not running out of ATM cards.

Findings in this study disclosed that some parents who are members of this program are buying accessories for themselves and other materials such as kitchen utensils and even appliances which is supposed to be for the education of the children. In same article, Albano said that Pecua and Teacher III Gloria Salitan, also of the DIS, estimate that three to five of 104Ps families in the barangay do not use the education support of their children as intended to the point that some 4Ps children come to school without school supplies and even barefoot. "There are those engaged in gambling and drinking that's why the needs of the children are not met. In the last quarter of the year, they run out of school supplies. To keep them from dropping out and affecting the school's performance, we provide their school supplies," Salitan said.

\section{Conclusions:-}

The findings of the study led to the following conclusions: 
1. There were 140 total respondents of the study from the identified barangays of Tabuk city of which the female group are higher in number representing $63 \%$ of the population. Married individuals composed most of the population with some who are single, separated and widow/widower. Furthermore, there is a relatively low level of educational attainment with the highest number of respondents being high school graduate, high school level, elementary graduate and elementary level. A mere 7\% have reached or finished college education.

2. The highest number of respondents are the Ilocano who are the major constituents of the said barangays followed by the Kalinga and Tagalog group. Further shown that almost all of the tribes inhabiting the identified places are recipients and beneficiaries of the government program. Occupation includes housekeeping , farming, operation of small business such as sari-sari store, rolling vendor and house-to-house selling with the least obtained result on hired labor.

3. There are 560 children of the beneficiary households who are attending school at different grade levels starting from pre-school, elementary and secondary with the majority at elementary level. An average of 4 children per household who are benefited by the Program including their education.

4. The goals and objectives of the Program are moderately with a total average weighted mean of 2.87 . Furthermore, there is a relatively low level on the attainment of the goals and objectives as assessed individually.

5. The Program have a moderate impact on the households with the highest assessments along, reduce the incidence of child labor and increase the enrolment and attendance rate of children in school both described as moderate impact.

6. The identified constraints have affected the implementation of the Program to a much serious extent with most of the individual indicators assessed as either very much or much serious. Such over-all and individual results dispelled the not-so commendable mode of poverty alleviation when taken in its total perspective.

Recommendations

Basing from the findings and the conclusions, the study recommends the following:

1. There is a need to device a built-in program that seek to ensure the economic sustainability of the program such that, the impact of the infusion of the financial assistance be felt in the longer future.

2. Simultaneously, members, while receiving financial assistance through the Program should be indoctrinated, reoriented and trained to empower themselves through the provision of necessary skills and competencies as a way to develop their capability for a productive activities that could help them earn sustainable income.

3. Not to mention the limited human resources by the implementing agency to do regular and close monitoring of the members, there is a need to develop a mechanics for the necessary conduct of proper monitoring and evaluation giving emphasis on the rightful attitude and character of a worthy recipient. Discourage indolence by possibly helping them venture into productive activities while enjoying the benefit of the program.

4. Implement close monitoring of members and giving full restriction of careless borrowing by using their cash cards as collateral. If possible, cashcards are released only to the rightful owners during pay-out. As such, they have nothing to use as collateral to abusive moneylenders, hence, helping the member instill discipline on cash handling and also discourage the habitual borrowing of money. Close and frequent monitoring likewise be done to ensure that the financial assistance is used by the member properly.

\section{References:-}

1. Albano, Estanislao Jr.(2018). Manila Times, Jul8 8 and 10, 2018

2. Mayo, Elton(2006). Human Problems of an Industrial Society. New York:Worth Publishers Incorporated

3. Longan, Mary Ruth(2016), "The Impact of the Pantawid Pamilyang Pilipino Program to the Economic Status of the People in Bado Dangwa, Tabuk City, Kalinga.

4. Pantawid Pamilya Guide Booklet 